\title{
The plant microbiome
}

Thomas R Turner', Euan K James² and Philip S Poole ${ }^{* *}$

\begin{abstract}
Plant genomes contribute to the structure and function of the plant microbiome, a key determinant of plant health and productivity. High-throughput technologies are revealing interactions between these complex communities and their hosts in unprecedented detail.
\end{abstract}

Keywords: Endophyte, microbiome, phyllosphere, rhizosphere

\section{Introduction}

Microbes are fundamental to the maintenance of life on Earth, yet we understand little about the majority of microbes in environments such as soils, oceans, the atmosphere and even those living on and in our own bodies. Culture-based techniques have allowed isolated microbes to be studied in detail, and molecular techniques such as metagenomics are increasingly allowing the identification of microbes in situ. The microbial communities, or microbiomes, of diverse environments have been studied in this way, with the goal of understanding their ecological function $[1,2]$.

The plant microbiome is a key determinant of plant health and productivity [3] and has received substantial attention in recent years $[4,5]$. A testament to the importance of plant-microbe interactions are the mycorrhizal fungi. Molecular evidence suggests that their associations with green algae were fundamental to the evolution of land plants about 700 million years ago [6]. Most plants, although notably not Arabidopsis thaliana and other Brassicaceae, have maintained this symbiosis, which assists root uptake of mineral nutrients such as phosphate [7]. Plant-associated microbes are also key players in global biogeochemical cycles [8]. A significant amount, 5 to $20 \%$, of the products of photosynthesis (the photosynthate) is released, mainly into the rhizosphere (the

*Correspondence: philip.poole@jic.ac.uk

'John Innes Centre, Norwich Research Park, Norwich NR4 7UH, UK Full list of author information is available at the end of the article soil-root interface) through roots [9]. In addition, $100 \mathrm{Tg}$ of methanol and $500 \mathrm{Tg}$ of isoprene are released into the atmosphere by plants annually $[10,11]$. For methanol this corresponds to between $0.016 \%$ and $0.14 \%$ of photosynthate depending on plant type [10]. Both are potential sources of carbon and energy for microorganisms. In agricultural soils in particular, plants stimulate microbial denitrification and methanogenesis, which contribute to emissions of $\mathrm{N}_{2} \mathrm{O}$ and methane, respectively $[12,13]$. These gases represent a loss of carbon and nitrogen from the system and contribute to the greenhouse effect.

Manipulation of the plant microbiome has the potential to reduce the incidence of plant disease $[14,15]$, increase agricultural production [16], reduce chemical inputs [17] and reduce emissions of greenhouse gases [18], resulting in more sustainable agricultural practices. This goal is seen as vital for sustaining the world's growing population.

Virtually all tissues of a plant host a microbial community. Here, we focus on the rhizosphere, phyllosphere (plant aerial surfaces) and endosphere (internal tissues). The rhizosphere is a region of rich, largely soilderived, microbial diversity, influenced by deposition of plant mucilage and root exudates [19]. By contrast, the phyllosphere is relatively nutrient poor and subject to extremes of temperature, radiation and moisture [20]. Microbial inhabitants of the rhizosphere and phyllosphere (those near or on plant tissue) are considered epiphytes, whereas microbes residing within plant tissues (the endosphere), whether in leaves, roots or stems, are considered endophytes. Microbes in these niches can establish beneficial, neutral or detrimental associations of varying intimacy with their host plants. Specific interactions between microbes and model plants, such as in Rhizobium-legume symbioses [21], are well understood, but the majority of the plant microbiome, and its contribution to the extended phenotype of the host, is not yet well defined. Importantly, the microbiome is strongly influenced by the plant genome and may be considered as an extension to form a second genome or collectively to form a pan-genome.

\section{Approaches for studying the plant microbiome}

Classic microbiology involves isolating and culturing microbes from an environment using different nutrient media and growth conditions depending on the target 
organisms. Although obtaining a pure culture of an organism is required for detailed studies of its genetics and physiology, culture-dependent techniques miss the vast majority of microbial diversity in an environment. Numerous culture-independent, molecular techniques are used in microbial ecology. For studying prokaryotes, PCR amplification of the ubiquitous $16 \mathrm{~S}$ ribosomal RNA (rRNA) gene is commonly used. Sequencing the variable regions of this gene allows precise (species- and strainlevel) taxonomic identification. The use of high-throughput sequencing technologies [22,23] has been widely adopted as they allow identification of thousands to millions of sequences in a sample, revealing the abundances of even rare microbial species. For studying eukaryotic microbes such as fungi, the equivalent rRNA gene (18S) may not provide sufficient taxonomic discrimination so the hypervariable internally transcribed spacer is often used.

A limitation of this is that PCR amplification of genomic DNA is inherently biased by primer design $[24,25]$ and generally only identifies the target organisms. Complex environments are inhabited by organisms from all domains of life. Eukaryotes, including fungi, protozoa, oomycetes and nematodes, are ubiquitous in soils and can be important plant pathogens or symbionts, whereas others are bacterial grazers. The archaea carry out important biochemical reactions, particularly in agricultural soils, such as ammonia oxidation [26] and methanogenesis [13]. Viruses too are abundant and widespread and can affect the metabolism and population dynamics of their hosts [27]. Microbes in a community interact with each other and the host plant [28], so it is important to capture as much of the diversity of a microbiome as possible. To do so requires the use of global analyses such as metagenomics, metatranscriptomics and metaproteomics, which allow simultaneous assessment and comparison of microbial populations across all domains of life. Metagenomics can reveal the functional potential of a microbiome (the abundance of genes involved in particular metabolic processes), whereas metatranscriptomics and metaproteomics provide snapshots of community-wide gene expression and protein abundance, respectively.

Metatranscriptomics has revealed kingdom-level changes in the structure of crop-plant rhizosphere microbiomes [29]. The relative abundance of eukaryotes in pea and oat rhizospheres was five-fold higher than in plant-free soil or the rhizosphere of modern hexaploid wheat. The pea rhizosphere in particular was highly enriched with fungi. Additional molecular techniques can complement such approaches. For example, stable isotope probing allows organisms metabolizing a particular labeled substrate to be identified [30]. This has been used in studies of rhizosphere microbiomes where ${ }^{13} \mathrm{CO}_{2}$ was fed to plants and fixed by photosynthesis, revealing that a subset of the microbial community actively metabolized plant-derived carbon [31,32]. Combining these techniques with culture-based approaches should improve our understanding of plant-microbe interactions at the systems level.

\section{The rhizosphere environment}

The rhizosphere is the region of soil influenced by plant roots through rhizodeposition of exudates, mucilage and sloughed cells. Root exudates contain a variety of compounds, predominately organic acids and sugars, but also amino acids, fatty acids, vitamins, growth factors, hormones and antimicrobial compounds [33]. Root exudates are key determinants of rhizosphere microbiome structure [34-37]. The composition of root exudates can vary between plant species and cultivars [38,39], and with plant age and developmental stage [40-42]. Also, the microbiome influences root exudates, as axenically grown (sterile) plants have markedly different exudate compositions from those influenced by microbes. Some accessions of $A$. thaliana have been shown to have different root exudate compositions and correspondingly different rhizosphere bacterial communities [38], whereas the rhizosphere bacterial communities of other accessions have shown high similarity $[43,44]$, although root exudates were not analyzed in the latter two studies.

Root exudates are not the only component of rhizodeposition. The sloughing of root cells and the release of mucilage deposits a large amount of material into the rhizosphere, including plant cell wall polymers such as cellulose and pectin [45]. Cellulose degradation is widespread among microbial residents of high-organic-matter soils $[46,47]$. The decomposition of pectin releases methanol [10], which can be used as a carbon source by other microbes, and active metabolism of methanol in the rhizosphere has been observed [48]. As well as providing a carbon source to rhizosphere microbes, plant roots also provide a structure on which microbes can attach. Supporting this is the observation of significant overlap between bacteria attaching to a root and to an inert wooden structure [44].

Studies of rhizosphere microbiomes have revealed remarkably similar distributions of microbial phyla $[29,43,44]$. Differences between plant cultivars become apparent when comparing microbial species and strains $[49,50]$. The Proteobacteria usually dominate samples, particularly those of the $\alpha$ and $\beta$ classes. Other major groups include Actinobacteria, Firmicutes, Bacteroidetes, Planctomycetes, Verrucomicrobia and Acidobacteria.

Of particular interest in the rhizosphere are plantgrowth-promoting rhizobacteria, which act through a variety of mechanisms [14]. Nitrogen-fixing bacteria, including those that are free-living (such as Azotobacter 
spp.) and symbiotic (such as root-nodulating Rhizobium spp.), provide a source of fixed nitrogen for the plant, and many bacteria can solubilize phosphorous-containing minerals, increasing its bioavailability. Microbial manipulation of plant hormones, particularly auxins, gibberellins and ethylene, can also lead to growth promotion or stress tolerance. Many plant-growth-promoting rhizobacteria act antagonistically towards plant pathogens by producing antimicrobials or by interfering with virulence factors via effectors delivered by type 3 secretion systems (T3SSs) [51]. Actinomycetes, in particular, are known to produce a wide array of compounds with antibacterial, antifungal, antiviral, nematicidal and insecticidal properties. They are often found as one of the most abundant bacterial classes in soil and rhizospheres, and are notably enriched in endophytic communities.

Other bacteria also act as disease antagonists, including Pseudomonas fluorescens, which produces the antifungal compound diacetylphloroglucinol (DAPG). Pseudomonas spp. producing DAPG have also been shown to modulate transcription in another plant-growth-promoting rhizobacterium, Azospirillum brasilense, increasing expression of genes involved in wheat root colonization and plantgrowth promotion [52]. DAPG also affects other microbiota, including nematodes, where it was found to be toxic to some species but stimulatory to others [53]. The presence of DAPG-producing Pseudomonas spp. in soils has been implicated in the phenomenon of take-all decline. Take-all is a cereal disease caused by the fungus Gaeumannomyces graminis. In take-all decline, disease severity reduces with repeated cultivation of a plant such as wheat. The soil becomes disease suppressive as a result of the establishment of antagonistic microbial communities [54]. Other antagonists from the Proteobacteria, Firmicutes and Actinobacteria contributed to soils suppressive towards the root-rotting fungus Rhizoctonia [55]; antifungal-metabolite-producing pseudomonads were one of the main groups responsible for suppression. Shifts in microbiomes have also been associated with soils suppressive towards Fusarium [56] and Streptomyces scabies [57]. This suggests that a consortium of microbes contributes to suppressiveness, although cause and effect are often not distinguishable. A rich and diverse microbiota alone may be sufficient to prevent infection by limiting access to roots and nutrients.

\section{The phyllosphere environment}

The phyllosphere, or aerial surface of a plant, is considered relatively nutrient poor compared with the rhizosphere. Microbial colonization of leaves is not homogenous but is affected by leaf structures such as veins, hairs and stomata. Leaf surfaces are colonized by up to $10^{7}$ microbes per $\mathrm{cm}^{2}$ [58]. The phyllosphere is a much more dynamic environment than the rhizosphere, with resident microbes subjected to large fluxes in temperature, moisture and radiation throughout the day and night. These abiotic factors also indirectly affect the phyllosphere microbiome through changes in plant metabolism. Precipitation and wind in particular are thought to contribute to the temporal variability in resident phyllosphere microbes [59]. Interestingly, leaf metabolite profiles of $A$. thaliana have been altered by application of soil microbes to roots: increased concentration of several amino acids in the leaf metabolome was correlated with increased herbivory by insects [60], suggesting cross-talk between above- and below-ground parts of the plant.

Bacterial and fungal communities in the phyllospheres of various plants have been profiled using PCR amplification of rRNA genes. Microbial richness seems to be greater in warmer, more humid climates than in temperate ones. Proteobacteria (the $\alpha$ and $\gamma$ classes) are consistently the dominant bacterial phylum, with Bacteroidetes and Actinobacteria also commonly found $[20,61]$. The phyllospheres of several plants in the Mediterranean were found to be dominated by lactic acid bacteria (Firmicutes) during summer. Their mode of metabolism was proposed to allow them to tolerate the hot and dry weather conditions [62], although this was not compared between different seasons. At high microbial taxonomic levels, phyllosphere microbiomes of different plants can seem similar, but at the microbial species and strain levels stark differences are apparent, reflecting the finely tuned metabolic adaptations required to live in such an environment [20]. Although rhizosphere microbiomes are comparable to soil, little similarity has been found between phyllosphere microbiomes and those of air [62].

Proteogenomic analyses of various phyllosphere microbiomes have revealed species that assimilate plantderived ammonium, amino acids and simple carbohydrates, implicating these compounds as primary nitrogen and carbon sources in the phyllosphere. Expression of microbial stress response proteins, porins, components of ATP binding cassette (ABC) transporters and TonBdependent receptors, particularly those from Sphingomonas spp., was high [48,63], indicating a nutrient-poor environment. These studies $[48,63]$ also determined that Methylobacterium spp. and other methylotrophs were widely abundant phyllosphere microbes, and that they were actively assimilating and metabolizing methanol derived from plant pectin [10]. Metagenomic analysis of taxonomically diverse plant species has identified an abundance of various known and novel microbial rhodopsins present in the phyllosphere. These lightsensing proteins and proton pumps showed non-overlapping absorption spectra with their host plant [64], showing that energy metabolism in the phyllosphere is not entirely dependent on the plant. 


\section{The endosphere environment}

Endophytic bacteria are those that reside for at least part of their lives within plant tissues [65-68]. They are generally considered to be non-pathogenic, causing no visible symptoms, but they include latent pathogens that, depending on environmental circumstances and/or host genotype, can cause disease [67,69]. Endophytes are thought to be a sub-population of the rhizosphere microbiome [66], but they also have characteristics distinct from rhizospheric bacteria, suggesting that not all rhizospheric bacteria can enter plants, and/or that once inside their hosts they change their metabolism and become adapted to their internal environment $[67,68,70]$. Although it is generally assumed that the bacteria that can be isolated from plant tissues after surface sterilization are 'endophytic', this may not be the case, as there are numerous niches on the surfaces of roots and aerial parts where bacteria can remain protected from the chemicals typically used for surface sterilization, and so confirmation that particular bacteria are truly endophytic must come from high-quality light microscopy (for example confocal) and/or transmission electron microscopy of fixed and resin-embedded samples $[66,67,71]$ (Figure 1). In two of the most recent studies, sonication was used to remove surface layers of plant tissue and the remaining tissue used to define the endophyte microbiome $[43,44]$. Such studies revealed that endophytic bacteria mostly reside in the intercellular apoplast and in dead or dying cells (Figure 1a-d), and as yet they have not been convincingly shown to occupy living cells in the same organized manner as true endosymbioses, such as that between legumes and rhizobia. They are also often found in the xylem vessels (Figure 1e,f), within which they may be translocated from the roots to the aerial parts.

But how do these bacteria initially enter their hosts? The best evidence suggests that they enter at lateral root junctions, most likely at naturally occurring cracks (Figure 1a,b) $[67,69,72,73]$. However, it should be stressed that this is unlikely to be an entirely passive process, as many endophytic bacteria express cell-wall-degrading enzymes (CWDEs), albeit generally in lower concentrations than expressed by plant pathogens [67]. Also, a few (for example, some Herbaspirillum spp. [67]) have been shown to possess T3SSs, which are the route of exit for excreted plant CWDEs, although most do not [68].

Other, more passive modes of entry are often through natural breaks in roots or root tips (Figure 1d) and/or by vegetative propagation; for example, stem seed pieces (pieces of cut sugarcane stem that contain at least one viable node from which a new plant can sprout) are a major source of the endophytic diazotroph population that colonizes the emerging sugarcane stalk and roots [69]. Once inside the roots, the bacteria colonize the apoplast, but their numbers seem to be controlled, as they rarely exceed $10^{7}$ to $10^{8}$ colony forming units (cfu) per gram fresh weight, and are often as low as $10^{3} \mathrm{cfu}$ per gram fresh weight, depending on plant age and genotype. Younger plants have higher bacterial concentrations than mature ones, and the concentrations of epiphytic bacteria are usually greater than those of endophytes, such as by a factor of ten in the case of Herbaspirillum [72]. To put these endophyte numbers into perspective, symbiotically effective legume nodules typically contain up to $10^{11} \mathrm{cfu}$ rhizobial bacteroids per gram fresh weight [74], so it would seem that the numbers of endophytic bacteria are not so high as to require the development of a specialized organ, such as a nodule, to house them. Indeed, high concentrations of endophytic bacteria (for example, over $10^{8} \mathrm{cfu}$ per gram fresh weight) can result in the elicitation of a host defense response [66,72] (Figure 1f). In addition, endophyte numbers are generally lower in aerial parts than in roots [67], which suggests that although there is some upward movement of endophytes within their hosts, perhaps through the transpiration stream, this movement is limited, and may only be possible for bacteria that express CWDEs and/or the T3SS $[66,67,72]$.

Most of our knowledge about endophytic bacteria comes from work on a few well studied 'model' organisms, such as Azoarcus, Burkholderia, Gluconacetobacter, Herbaspirillum and Klebsiella spp., which were all isolated from non-legumes, particularly grasses $[66,67$, 69,73,75]. Although these studies have given much insight into mechanisms of infection and colonization, they tell us little about the true diversity of the bacteria in the endophytic microbiome, and, indeed, they may not be particularly representative of it. Culture-independent methods, such as analyses of $16 \mathrm{~S}$ rRNA and nifH transcripts [76], and metagenome analyses [68] have demonstrated a huge diversity of endophytes in the economically important crops sugarcane and rice. Interestingly, these studies suggest that rhizobia (and other $\alpha$-Proteobacteria) are very common endophytes, as are $\beta$-Proteobacteria, $\gamma$ Proteobacteria and Firmicutes.

High-throughput sequencing of $16 \mathrm{~S}$ rRNA has recently been used to define the core endophytic bacterial microbiome of $A$. thaliana [43,44]. These studies showed that although various different soil types altered the bacterial endophyte microbiome, Actinobacteria and some families from the Proteobacteria were consistently enriched in the endosphere compared with the rhizosphere. The endophyte microbiomes seemed to be a subset of the rhizosphere microbiomes, indicating much stronger plant selection for the internal environment. This raises the important question of the role of plant immunity. Does innate immunity through the recognition of microbe-associated molecular patterns (MAMPs) have a role in selection of microbes? 


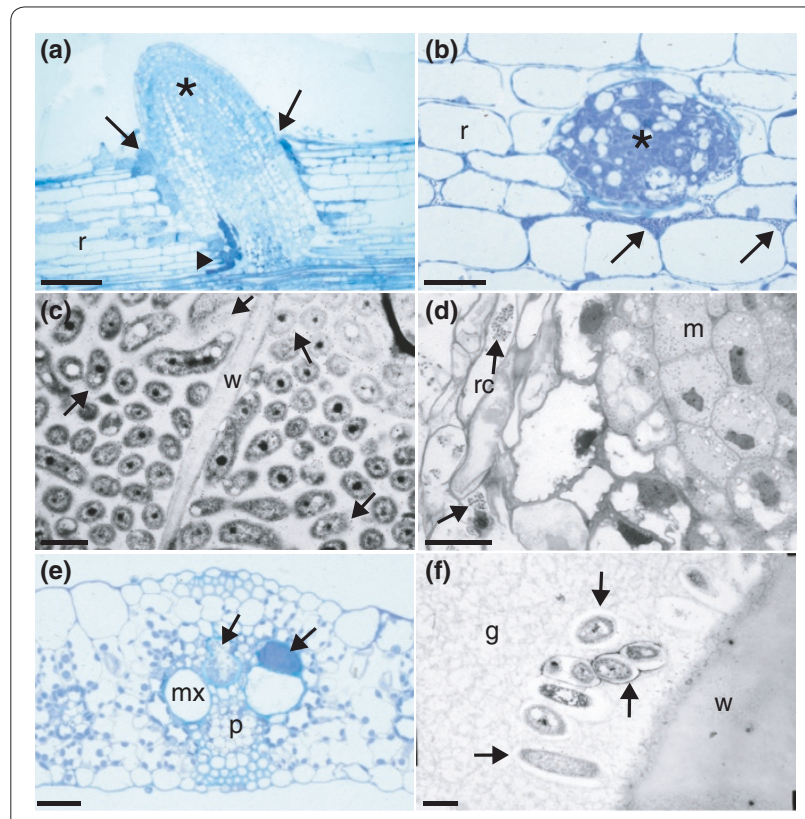

Figure 1. Light micrographs $(a, b, d, e)$ and transmission electron micrographs (TEMs) $(c, f)$ of colonization of poaceous crops by endophytic diazotrophic bacteria. (a) Longitudinal section of a rice (Oryza sativa) root ( $r$ ) being invaded by $\mathrm{H}$. seropedicae (arrows) at a lateral root (asterisk) junction. Bacteria have colonized intercellular spaces deep within the cortex of the main root (arrowhead). (b) Transverse section of a rice root ( $r$ ) showing that the intercellular spaces surrounding the point of emergence of an emerging lateral root (asterisk) are heavily colonized by $\mathrm{H}$. seropedicae (arrows). (c) Transmission electron micrograph of rice root cells that are densely colonized by $\mathrm{H}$. seropedicae, labeled by gold particles attached to an antibody against $H$. seropedicae strain Z67. The host cytoplasm is no longer present, but the bacteria are instead surrounded by exopolysaccharide material that is strongly labeled (see [72] for details). w, plant cell. (d) Longitudinal section of a sugarcane (Saccharum sp.) root tip being invaded by G. diazotrophicus. The bacteria (arrows) are present in the root cap cells $(r c)$, some of which are broken, but the newly divided cells of the meristem ( $m$ ) remain uninvaded. (e) Transverse section of a sorghum (Sorghum bicolor) leaf. The protoxylem and associated lacunae are densely colonized by H. rubrisubalbicans (arrows), but the metaxylem $(\mathrm{mx}$ ) remains uninvaded. p, phloem. (f) TEM of sugarcane leaf xylem colonized by G. diazotrophicus; the bacteria are healthy in appearance but are embedded in a gum (g) that was produced by the plant as a defense response to their presence. The bacteria accordingly have released exopolysaccharide to protect themselves from this gum, thus creating 'halo-like' electron-transparent regions around them (arrows). The scale bars represent (a) $50 \mu \mathrm{m}$, (b) $20 \mu \mathrm{m}$, (c) $1 \mu \mathrm{m}$, (d) $10 \mu \mathrm{m}$, (e) $20 \mu \mathrm{m}$ and (f) $1 \mu \mathrm{m}$.

On the plant side, the best studied systems have been those involving the inoculation of sugarcane and rice by defined strains of endophytic and/or rhizospheric bacteria, particularly Azospirillum, Burkholderia, Gluconacetobacter and Herbaspirillum spp. [77-80]. This subject has been reviewed recently [67]. The most important genomic response that has been reported in rice or sugarcane after inoculation with endophytic bacteria is modulation of the expression of plant defense-related genes, such as resistance (R) genes and leucine-rich repeat (LRR)-containing-receptor-like kinases; these are expressed at different levels (higher or lower) than typically occurs when the plants are challenged with phytopathogens without any endophytic bacteria. For example, when the sugarcane variety B4362, which is susceptible to mottled stripe disease, was inoculated with the causal organism, Herbaspirillum rubrisubalbicans [67], expression of the LRR-rich receptor-like kinase SHR5 was unaltered, whereas it decreased significantly in nonsusceptible varieties and when the same variety was challenged with Herbaspirillum seropedicae, a nonphytopathogenic endophytic relative of $H$. rubrisubalbicans [80]. Moreover, the ethylene receptors in sugarcane and rice are differentially expressed in response to endophytic bacteria; some, but not all, are upregulated, and the type of ethylene receptor that is expressed depends on which endophytic bacterial species is inoculated onto the plant [77,78]. In contrast, when sugarcane is challenged with phytopathogens such as Leifsonia xyli and sugarcane mosaic virus, ethylene response transcription factors (ERFs) that are repressed after inoculation with endophytic bacteria (such as SCERF1) are strongly upregulated [78]. Taken together, these genomic responses suggest that the plants are 'prepared' for their invasion by these 'friendly' bacteria in a manner that is very different to their reactions to phytopathogens.

Interestingly, many of these defense genes are also differentially expressed depending on the host and the bacterial genotype. The facts that they are so commonly isolated from almost all types of multicellular plants, and that there are specific plant genomic responses to them that are different from the responses of other types of plant-associated bacteria (such as phytopathogens) suggest that endophytic bacteria are at least tolerated by their hosts and may actually be welcomed by them. So what are the potential benefits (if any) to plants of endophytic bacteria? There have been many studies on 'endophytic diazotrophs' (nitrogen-fixing bacteria that live in plants, particularly in grasses), and there is evidence that these can express nif genes and proteins (which are involved in nitrogen fixation), and that they may even fix significant amounts of nitrogen and transfer it to their hosts [71-73]. There has also been much recent focus on endophytic bacteria that have plant-growth-promoting characteristics, such as hormone production (indoles, auxins), phosphate-solubilization, siderophores and 1-aminocyclopropane 1-carboxylic acid (ACC) deaminase $[66,68,75]$. It has been shown by some studies (for example, of sugarcane) that some endophytic bacteria are more likely to possess all or some of these plant-growth-promoting characteristics than epiphytic or rhizospheric bacteria on 
the same hosts [70]. In addition, it is known that plants that have been inoculated with endophytic bacteria, such as G. diazotrophicus and Herbaspirillum, may be better protected against phytopathogenic fungi and/or bacteria through systemically acquired resistance [67].

We know that inoculation with specific strains (either singly or in consortia) of endophytic bacteria that have plant-growth-promoting characteristics and/or diazotrophy can result in significant growth benefits to host plants; however, if we are to exploit the full potential of endophytic bacteria the challenge now is to determine several things about them and their hosts. First, we need to know whether these well studied strains and species are 'representative' of the endophytic bacterial populations that seem to naturally pertain in all higher plants. Second, we need to know whether endophytic bacteria are essential for the health of their hosts, and if so, whether it is possible to compare naturally 'bacterized' plants to those without any endophytic bacterial population. And third, we need to find out how we can exploit knowledge about the genomes of the host plants, particularly those of economically important crops, and how they respond to specific endophytic bacteria and/or to endophytic bacteria in general; in other words, whether we can carefully 'match' host and bacterial genotypes with the aim of optimizing their association in terms of crop productivity.

\section{The effect of the host on the plant microbiome}

The interactions between a plant and its microbiome are highly complex and dynamic. The plant immune system (Box 1) in particular is thought to have a key role in determining plant microbiome structure. Mutants of $A$. thaliana deficient in systemic acquired resistance (SAR) have shown differences in rhizosphere bacterial community composition compared with wild type [81], whereas chemical activation of SAR did not result in significant shifts in the rhizosphere bacterial community [82]. In the phyllosphere of $A$. thaliana, induction of salicylic-acidmediated defense reduced the diversity of endophytes, whereas plants deficient in jasmonate-mediated defense showed higher epiphytic diversity [83]. These reports suggest that the effects of plant defense processes on the microbiome are variable and that SAR is responsible for controlling the populations of some bacteria.

Production of plant hormones such as indole-3-acetic acid (IAA) is widespread among plant-associated bacteria, particularly the rhizobia [84], and some Bacillus spp. can produce gibberellins [85]. Pseudomonas syringae produces hormone analogs that interfere with jasmonate and ethylene signaling, resulting in stomatal opening and pathogen entry [86]. Degradation of hormones or hormone precursors by bacteria is also documented. For example, microbial deamination of ACC prevents plant

\section{Box 1. Plant immunity}

Plant innate immunity is triggered by exposure to microbes through microbe-associated molecular patterns (MAMPs)

[103]. Because many of these responses were first investigated in pathogenic microbes, they are also know as pathogenassociated molecular patterns (PAMPs) and the plant response is called PAMP-triggered immunity (PTI). MAMPS are widespread, slowly evolving features of bacteria and other microbes, such as flagellin, elongation factor Tu and chitin. The plant response includes production of reactive oxygen species, callose deposition (strengthening of cell walls) and activation of signaling and defense genes. Pathogens can affect these responses through secretion of effectors [104], which trigger a further response from the plant, known as effector-triggered immunity (ETI) [105]. Systemic acquired resistance (SAR), or priming, is activated by MAMP recognition and ETI. It is a plant-wide response involving the accumulation of broadspectrum antimicrobials in healthy tissue, limiting the spread of the infection. Plant defense signaling is coordinated by hormones depending on the type of pathogen [106]. Salicylic acid is produced in response to attack by biotrophic pathogens, whereas jasmonate controls responses to insect herbivores and necrotrophic pathogens. Ethylene is another plant hormone produced in response to herbivores, necrotrophic pathogens, and environmental and developmental signals. It can also modulate the jasmonate and salicylic acid signaling pathways. Plant immunity has co-evolved with the plant microbiome and thus is thought to have a key role in determining its structure.

ethylene signaling, resulting in plants more tolerant to environmental stress [87].

Although some chemical signals released by plants facilitate specific interactions, many are recognized by other organisms. For example, flavonoids trigger diverse responses in rhizobia, mycorrhiza, root pathogens and other plants [88]. Strigolactones induce hyphal branching in mycorrhizal fungi and promote seed germination of parasitic plants [89]. Some plant genes and pathways have roles in establishment of multiple interactions with different microbes; examples include the developmental pathways that are shared between mycorrhizal and rhizobial symbioses [90], the mycorrhizal symbiosis and infection by oomycetes [91] and the rhizobial symbiosis and infection by nematodes [92]. It is not yet known whether and how these pathways interact with other members of the microbiome.

Plants produce a wide variety of antimicrobial compounds both constitutively and in response to pathogens [93]. Phenolics, terpenoids and alkaloids are widespread in the plant kingdom, whereas others are restricted to particular groups [94]; glucosinolates, for example, are produced only by members of the order Brassicales. Arabidopsis produces glucosinolates naturally, but transgenic Arabidopsis producing an exogenous glucosinolate altered the bacterial and fungal communities in the 
rhizosphere and root tissue [95]. Oat (Avena strigosa) produces triterpenoid saponins known as avenacins, which have broad-spectrum antifungal activity [96]. Oat mutants lacking avenacins have different culturable communities of root-colonizing fungi [97] and are more susceptible to fungal pathogens than isogenic wild-type oat $[98,99]$. Surprisingly, however, a recent global analysis of the rhizosphere microbiome of these two genotypes found little difference between the fungal communities. The eukaryotic Amoebozoa and Alveolata were strongly affected by the lack of avenacins in the mutant, whereas bacterial communities were unaffected [29]. This highlights that a small change in plant genotype can have complex and unforeseen effects on the plant microbiome. Other studies have not found any significant differences in rhizosphere microbiomes between wild-type maize and maize genetically engineered to produce Bacillus thuringiensis $(\mathrm{Bt})$ toxin $[100,101]$, although this may be due to Bt toxin being insecticidal rather than antibacterial. Also, in the wheat rhizosphere, introduction of the $p m 3 b$ gene conferring resistance to mildew had minimal effect on pseudomonads and mycorrhizal fungi populations [102]. Disease resistance, including production of antimicrobial compounds, is a trait likely to be introduced as a result of molecular breeding or genetic modification in attempts to control diseases. These may or may not affect resident members of the microbiome, potentially with unforeseen effects on the plant, and should be assessed on an individual basis. This is particularly important given that the products of disease resistance genes are often unknown.

\section{Conclusions}

The microbiome can be considered as an extension of the host genome. Microbiomes associated with aboveground (phyllosphere), below-ground (rhizosphere) and internal (endosphere) tissues of the same plant are distinct. Also, microbiomes occupying the same niche of different plants can be very different, particularly when the microbiome is viewed at fine taxonomic levels such as genus, species and strain. This is where specific metabolic capabilities are required to use host-derived carbon sources and tolerate host defenses. Abiotic conditions, such as temperature, moisture and $\mathrm{pH}$, have broad affects on the microbiome directly and indirectly through the host. Phyllosphere microbial communities are subject to huge fluxes in abiotic conditions, and so rates of microbial turnover are different between different regions of the plant. In addition, there is cross-talk between above- and below-ground plant tissues, which can affect other external factors such as herbivory. Even small changes in the host genome can influence the plant microbiome, and these changes can feed back to modulate the behavior of the host.
Despite its complexity and dynamism, particularly in natural environments, it is important not to overlook the plant microbiome when interpreting experimental data, especially when it can lead to applications in the field. Genetic modification of plants, to resist disease for example, may have unforeseen consequences for the rest of the microbiome, which may or may not be physiologically relevant. The role of the microbiome and its relationship to plant health, productivity and biogeochemical cycles should be considered as much as the plant itself. An extension of this notion is that molecular breeding or genetic modification of plants could be used to modulate the microbiome intentionally, recruiting disease antagonists and plant-growth promoters to improve agricultural production.

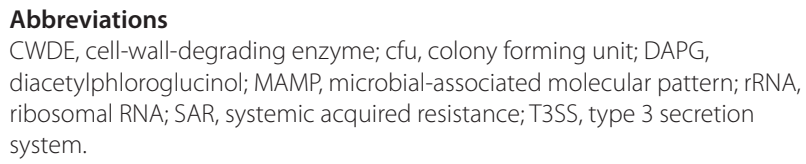

Acknowledgements

We thank Kate Bailey for helpful comments on the plant immunity section.

\section{Author details}

IJohn Innes Centre, Norwich Research Park, Norwich NR4 7UH, UK. ${ }^{2}$ The James Hutton Institute, Invergowrie, Dundee DD2 5DA, UK.

Published: 25 June 2013

\section{References}

1. Gilbert JA, Meyer F, Jansson J, Gordon J, Pace N, Tiedje J, Ley R, Fierer N, Field D, Kyrpides N, Glöckner FO, Klenk HP, Wommack KE, Glass E, Docherty K, Gallery R, Stevens R, Knight R: The Earth Microbiome Project: meeting report of the "1st EMP meeting on sample selection and acquisition" at Argonne National Laboratory October 6 2010. Stand Genomic Sci 2010, 3:249-253.

2. Turnbaugh PJ, Ley RE, Hamady M, Fraser-Liggett CM, Knight R, Gordon J: The Human Microbiome Project. Nature 2007, 449:804-810.

3. Berendsen RL, Pieterse CMJ, Bakker P: The rhizosphere microbiome and plant health. Trends Plant Sci 2012, 17:478-486.

4. Lebeis SL, Rott M, Dangl JL, Schulze-Lefert P: Culturing a plant microbiome community at the cross-Rhodes. New Phyto/ 2012, 196:341-344.

5. Bulgarelli D, Schlaeppi K, Spaepen S, Ver Loren van Themaat E, Schulze-Lefert P: Structure and functions of the bacterial microbiota of plants. Annu Rev Plant Biol 2013, 64:807-838.

6. Heckman DS, Geiser DM, Eidell BR, Stauffer RL, Kardos NL, Hedges SB: Molecular evidence for the early colonization of land by fungi and plants. Science 2001, 293:1129-1133.

7. Bonfante P: Plant-fungal interactions in mycorrhizas. In eLS. Wiley; 2010.

8. Philippot L, Hallin S, Borjesson G, Baggs EM: Biochemical cycling in the rhizosphere having an impact on global change. Plant Soil 2009, 321:61-81

9. Marschner: Mineral Nutrition in Higher Plants. 2nd edition. London: Academic Press; 1995.

10. Galbally IE, Kirstine W: The production of methanol by flowering plants and the global cycle of methanol. J Atmos Chem 2002, 43:195-229.

11. Wang KY, Shallcross DE: Modelling terrestrial biogenic isoprene fluxes and their potential impact on global chemical species using a coupled LSMCTM model. Atmos Environ 2000, 34:2909-2925.

12. Wrage $N$, Velthof $G L$, van Beusichem ML, Oenema O: Role of nitrifier denitrification in the production of nitrous oxide. Soil Biol Biochem 2001, 33:1723-1732. 
13. Conrad R, Erkel C, Liesack W: Rice Cluster I methanogens, an important group of Archaea producing greenhouse gas in soil. Curr Opin Biotechnol 2006, 17:262-267.

14. Bloemberg GV, Lugtenberg BJJ: Molecular basis of plant growth promotion and biocontrol by rhizobacteria. Curr Opin Plant Bio/ 2001, 4:343-350.

15. Andrews JH: Biological-control in the phyllosphere. Annu Rev Phytopathol 1992, 30:603-635.

16. Bakker MG, Manter DK, Sheflin AM, Weir TL, Vivanco JM: Harnessing the rhizosphere microbiome through plant breeding and agricultural management. Plant Soil 2012, 360:1-13.

17. Adesemoye AO, Torbert HA, Kloepper JW: Plant growth-promoting rhizobacteria allow reduced application rates of chemical fertilizers. Microb Ecol 2009, 58:921-929.

18. Singh BK, Bardgett RD, Smith P, Reay DS: Microorganisms and climate change: terrestrial feedbacks and mitigation options. Nat Rev Microbiol 2010, 8:779-790.

19. Kent AD, Triplett EW: Microbial communities and their interactions in soil and rhizosphere ecosystems. Annu Rev Microbio/ 2002, 56:211-236.

20. Vorholt JA: Microbial life in the phyllosphere. Nat Rev Microbio/ 2012 10:828-840.

21. Oldroyd GED, Murray JD, Poole PS, Downie JA: The rules of engagement in the legume-rhizobial symbiosis. Annu Rev Genet 2011, 45:119-144.

22. Bentley DR, Balasubramanian S, Swerdlow HP, Smith GP, Milton J, Brown CG, Hall KP, Evers DJ, Barnes CL, Bignell HR, Boutell JM, Bryant J, Carter RJ, Keira Cheetham R, Cox AJ, Ellis DJ, Flatbush MR, Gormley NA, Humphray SJ, Irving LJ, Karbelashvili MS, Kirk SM, Li H, Liu X, Maisinger KS, Murray LJ, Obradovic B, Ost T, Parkinson ML, Pratt MR, et al:: Accurate whole human genome sequencing using reversible terminator chemistry. Nature 2008, 456:53-59.

23. Margulies M, Egholm M, Altman WE, Attiya S, Bader JS, Bemben LA, Berka J, Braverman MS, Chen YJ, Chen Z, Dewell SB, Du L, Fierro JM, Gomes XV, Godwin BC, He W, Helgesen S, Ho CH, Irzyk GP, Jando SC, Alenquer ML, Jarvie $T P$, Jirage KB, Kim JB, Knight JR, Lanza JR, Leamon JH, Lefkowitz SM, Lei M, Li J, et al:: Genome sequencing in microfabricated high-density picolitre reactors. Nature 2005, 437:376-380

24. Hong SH, Bunge J, Leslin C, Jeon S, Epstein SS: Polymerase chain reaction primers miss half of rRNA microbial diversity. ISME J 2009, 3:1365-1373.

25. Pinto AJ, Raskin L: PCR biases distort bacterial and archaeal community structure in pyrosequencing datasets. PLoS One 2012, 7:16.

26. Leininger S, Urich T, Schloter M, Schwark L, Qi J, Nicol GW, Prosser Jl, Schuster SC, Schleper C: Archaea predominate among ammonia-oxidizing prokaryotes in soils. Nature 2006, 442:806-809

27. Williams SCP: The other microbiome. Proc Natl Acad Sci U S A 2013, 110:2682-2684.

28. Barea JM, Pozo MJ, Azcon R, Azcon-Aguilar C: Microbial co-operation in the rhizosphere. J Exp Bot 2005, 56:1761-1778.

29. Turner T, Ramakrishnan K, Walshaw J, Heavens D, Alston M, Swarbreck D, Osbourn A, Grant A, Poole P: Comparative metatranscriptomics reveals kingdom level changes in the rhizosphere microbiome of plants. ISME 2013, in press.

30. Radajewski S, Ineson P, Parekh NR, Murrell JC: Stable-isotope probing as a tool in microbial ecology. Nature 2000, 403:646-649.

31. Haichar FE, Marol C, Berge O, Rangel-Castro Jl, Prosser Jl, Balesdent J, Heulin T, Achouak W: Plant host habitat and root exudates shape soil bacterial community structure. ISME J 2008, 2:1221-1230.

32. Lu YH, Rosencrantz D, Liesack W, Conrad R: Structure and activity of bacterial community inhabiting rice roots and the rhizosphere. Environ Microbio/ 2006, 8:1351-1360.

33. Bertin $\mathrm{C}$, Yang $\mathrm{XH}$, Weston $\mathrm{LA}$ : The role of root exudates and allelochemicals in the rhizosphere. Plant Soil 2003, 256:67-83.

34. Shi SJ, Richardson AE, O'Callaghan M, DeAngelis KM, Jones EE, Stewart A, Firestone MK, Condron LM: Effects of selected root exudate components on soil bacterial communities. FEMS Microbiol Ecol 2011, 77:600-610.

35. Bais HP, Weir TL, Perry LG, Gilroy S, Vivanco JM: The role of root exudates in rhizosphere interations with plants and other organisms. Annu Rev Plant Biol 2006, 57:233-266.

36. Broeckling CD, Broz AK, Bergelson J, Manter DK, Vivanco JM: Root exudates regulate soil fungal community composition and diversty. Appl Environ Microbiol 2008, 74:738-744

37. Badri DV, Chaparro JM, Zhang R, Shen Q, Vivanco JM: Application of natural blends of phytochemicals derived from the root exudates of Arabidopsis to the soil reveal that phenolic-related compounds predominantly modulate the soil microbiome. J Biol Chem 2013, 288:4502-4512.

38. Micallef SA, Shiaris MP, Colon-Carmona A: Influence of Arabidopsis thaliana accessions on rhizobacterial communities and natural variation in root exudates. J Exp Bot 2009, 60:1729-1742.

39. Mark GL, Dow JM, Kiely PD, Higgins H, Haynes J, Baysse C, Abbas A, Foley T, Franks A, Morrissey J, O'Gara F: Transcriptome profiling of bacterial responses to root exudates identifies genes involved in microbe-plant interactions. Proc Natl Acad Sci U S A 2005, 102:17454-17459.

40. DeAngelis KM, Brodie EL, DeSantis TZ, Andersen GL, Lindow SE, Firestone MK Selective progressive response of soil microbial community to wild oat roots. ISME J 2009, 3:168-178.

41. Chaparro JM, Badri DV, Bakker MG, Sugiyama A, Manter DK, Vivanco JM: Root exudation of phytochemicals in Arabidopsis follows specific patterns that are developmentally programmed and correlate with soil microbial functions. PLoS One 2013, 8:10.

42. Cavaglieri L, Orlando J, Etcheverry M: Rhizosphere microbial community structure at different maize plant growth stages and root locations. Microbiol Res 2009, 164:391-399.

43. Lundberg DS, Lebeis SL, Paredes SH, Yourstone S, Gehring J, Malfatti S, Tremblay J, Engelbrektson A, Kunin V, del Rio TG, Edgar RC, Eickhorst T, Ley RE, Hugenholtz P, Tringe SG, Dangl JL: Defining the core Arabidopsis thaliana root microbiome. Nature 2012, 488:86-90.

44. Bulgarelli D, Rott M, Schlaeppi K, Ver Loren van Themaat E, Ahmadinejad N, Assenza F, Rauf P, Huettel B, Reinhardt R, Schmelzer E, Peplies J, Gloeckner FO, Amann R, Eickhorst T, Schulze-Lefert P: Revealing structure and assembly cues for Arabidopsis root-inhabiting bacterial microbiota. Nature 2012, 488:91-95.

45. Dennis PG, Miller AJ, Hirsch PR: Are root exudates more important than other sources of rhizodeposits in structuring rhizosphere bacterial communities? FEMS Microbiol Ecol 2010, 72:313-327

46. Stursova M, Zifcakova L, Leigh MB, Burgess R, Baldrian P: Cellulose utilization in forest litter and soil: identification of bacterial and fungal decomposers. FEMS Microbiol Ecol 2012, 80:735-746.

47. Haichar FEZ, Achouak W, Christen R, Heulin T, Marol C, Marais MF, Mougel C, Ranjard L, Balesdent J, Berge O: Identification of cellulolytic bacteria in soil by stable isotope probing. Environ Microbio/ 2007, 9:625-634.

48. Knief C, Delmotte N, Chaffron S, Stark M, Innerebner G, Wassmann R, von Mering C, Vorholt JA: Metaproteogenomic analysis of microbial communities in the phyllosphere and rhizosphere of rice. ISME J 2012, 6:1378-1390.

49. Inceoglu O, Abu Al-Soud W, Salles JF, Semenov AV, van Elsas JD: Comparative analysis of bacterial communities in a potato field as determined by pyrosequencing. PLoS One 2011, 6:11.

50. Teixeira L, Peixoto RS, Cury JC, Sul WJ, Pellizari VH, Tiedje J, Rosado AS: Bacterial diversity in rhizosphere soil from Antarctic vascular plants of Admiralty Bay, maritime Antarctica. ISME J 2010, 4:989-1001.

51. Rezzonico F, Binder C, Defago G, Moenne-Loccoz Y: The type III secretion system of biocontrol Pseudomonas fluorescens KD targets the phytopathogenic chromista Pythium ultimum and promotes cucumber protection. Mol Plant Microbe Interact 2005, 18:991-1001.

52. Combes-Meynet E, Pothier JF, Moenne-Loccoz Y, Prigent-Combaret C: The Pseudomonas secondary metabolite 2,4-diacetylphloroglucinol is a signal inducing rhizoplane expression of Azospirillum genes involved in plantgrowth promotion. Mol Plant Microbe Interact 2011, 24:271-284.

53. Meyer SLF, Halbrendt JM, Carta LK, Skantar AM, Liu T, Abdelnabby HME, Vinyard BT: Toxicity of 2,4-diacetylphloroglucinol (DAPG) to plant-parasitic and bacterial-feeding nematodes. J Nematol 2009, 41:274-280.

54. Raaijmakers JM, Weller DM: Natural plant protection by 2,4-diacetylphloroglucinol-producing Pseudomonas spp. in take-al decline soils. Mol Plant Microbe Interact 1998, 11:144-152.

55. Mendes R, Kruijt M, de Bruijn I, Dekkers E, van der Voort M, Schneider JH, Piceno YM, DeSantis TZ, Andersen GL, Bakker PA, Raaijmakers JM: Deciphering the rhizosphere microbiome for disease-suppressive bacteria. Science 2011, 332:1097-1100.

56. Klein E, Ofek M, Katan J, Minz D, Gamliel A: Soil suppressiveness to Fusarium disease: shifts in root microbiome associated with reduction of pathogen root colonization. Phytopathology 2013, 103:23-33.

57. Rosenzweig N, Tiedje JM, Quensen JF, Meng QX, Hao JJJ: Microbial communities associated with potato common scab-suppressive soil determined by pyrosequencing analyses. Plant Dis 2012, 96:718-725.

58. Lindow SE, Brandl MT: Microbiology of the phyllosphere. Appl Environ 
Microbiol 2003, 69:1875-1883

59. Lindow SE: Role of immigration and other processes in determining epiphytic bacterial populations - implications for disease management. In Aerial Plant Surface Microbiology. New York: Plenum; 1996:155-168.

60. Badri DV, Zolla G, Bakker MG, Manter DK, Vivanco JM: Potential impact of soil microbiomes on the leaf metabolome and on herbivore feeding behavior. New Phytol 2013, 198:264-273.

61. Bodenhausen N, Horton MW, Bergelson J: Bacterial communities associated with the leaves and the roots of Arabidopsis thaliana. PLoS One 2013, 8:e56329

62. Vokou D, Vareli K, Zarali E, Karamanoli K, Constantinidou HIA, Monokrousos N, Halley JM, Sainis I: Exploring biodiversity in the bacterial community of the Mediterranean phyllosphere and its relationship with airborne bacteria. Microb Ecol 2012, 64:714-724.

63. Delmotte N, Knief C, Chaffron S, Innerebner G, Roschitzki B, Schlapbach R, von Mering C, Vorholt JA: Community proteogenomics reveals insights into the physiology of phyllosphere bacteria. Proc Natl Acad Sci U S A 2009, 106:16428-16433.

64. Atamna-Ismaeel N, Finkel OM, Glaser F, Sharon I, Schneider R, Post AF, Spudich JL, von Mering C, Vorholt JA, lluz D, Béjà O, Belkin S: Microbial rhodopsins on leaf surfaces of terrestrial plants. Environ Microbiol 2012, 14:140-146.

65. Hallmann J, QuadtHallmann A, Mahaffee WF, Kloepper JW: Bacterial endophytes in agricultural crops. Can J Microbiol 1997, 43:895-914.

66. Compant S, Clement C, Sessitsch A: Plant growth-promoting bacteria in the rhizo- and endosphere of plants: their role, colonization, mechanisms involved and prospects for utilization. Soil Biol Biochem 2010, 42:669-678

67. Monteiro RA, Balsanelli E, Wassem R, Marin AM, Brusamarello-Santos LCC, Schmidt MA, Tadra-Sfeir MZ, Pankievicz VCS, Cruz LM, Chubatsu LS, Pedrosa FO, Souza EM: Herbaspirillum-plant interactions: microscopical, histological and molecular aspects. Plant Soil 2012, 356:175-196.

68. Sessitsch A, Hardoim P, Doring J, Weilharter A, Krause A, Woyke T, Mitter B, Hauberg-Lotte L, Friedrich F, Rahalkar M, Hurek T, Sarkar A, Bodrossy L, van Overbeek L, Brar D, van Elsas JD, Reinhold-Hurek B: Functional characteristics of an endophyte community colonizing rice roots as revealed by metagenomic analysis. Mol Plant Microbe Interact 2012, 25:28-36

69. James EK, Olivares FL: Infection and colonization of sugar cane and other graminaceous plants by endophytic diazotrophs. Crit Rev Plant Sci 1998, 17:77-119.

70. Ferrara FID, Oliveira ZM, Gonzales HHS, Floh EIS, Barbosa HR: Endophytic and rhizospheric enterobacteria isolated from sugar cane have different potentials for producing plant growth-promoting substances. Plant Soil 2012, 353:409-417.

71. James EK: Nitrogen fixation in endophytic and associative symbiosis. Field Crop Res 2000, 65:197-209.

72. James EK, Gyaneshwar P, Mathan N, Barraquio QL, Reddy PM, lannetta PPM, Olivares FL, Ladha JK: Infection and colonization of rice seedlings by the plant growth-promoting bacterium Herbaspirillum seropedicae Z67. Mol Plant Microbe Interact 2002, 15:894-906.

73. Reinhold-Hurek B, Hurek T: Living inside plants: bacterial endophytes. Curr Opin Plant Biol 2011, 14:435-443.

74. Muller J, Wiemken A, Boller T: Redifferentiation of bacteria isolated from Lotus japonicus root nodules colonized by Rhizobium sp NGR234. J Exp Bot 2001, 52:2181-2186

75. Suarez-Moreno ZR, Caballero-Mellado J, Coutinho BG, Mendonca-Previato L, James EK, Venturi V: Common features of environmental and potentially beneficial plant-associated Burkholderia. Microb Ecol 2012, 63:249-266.

76. Fischer D, Pfitzner B, Schmid M, Simões-Araújo JL, Reis VM, Pereira W, Ormeño-Orrillo E, Hai B, Hofmann A, Schloter M, Martinez-Romero E, Baldani Jl, Hartmann A: Molecular characterisation of the diazotrophic bacterial community in uninoculated and inoculated field-grown sugarcane (Saccharum sp.). Plant Soil 2012, 356:83-99.

77. Brusamarello-Santos LCC, Pacheco F, Aljanabi SMM, Monteiro RA, Cruz LM, Baura VA, Pedrosa FO, Souza EM, Wassem R: Differential gene expression of rice roots inoculated with the diazotroph Herbaspirillum seropedicae. Plant Soil 2012, 356:113-125

78. Cavalcante JJV, Vargas C, Nogueira EM, Vinagre F, Schwarcz K, Baldani II, Ferreira PCG, Hemerly AS: Members of the ethylene signalling pathway are regulated in sugarcane during the association with nitrogen-fixing endophytic bacteria. J Exp Bot 2007, 58:673-686.

79. Vargas L, de Carvalho TLG, Ferreira PCG, Baldani VLD, Baldani JI, Hemerly AS:
Early responses of rice (Oryza sativa L.) seedlings to inoculation with beneficial diazotrophic bacteria are dependent on plant and bacterial genotypes. Plant Soil 2012, 356:127-137.

80. Vinagre F, Vargas C, Schwarcz K, Cavalcante J, Nogueira EM, Baldani JI, Ferreira PCG, Hemerly AS: SHR5: a novel plant receptor kinase involved in plant-N2-fixing endophytic bacteria association. J Exp Bot 2006, 57:559-569.

81. Hein JW, Wolfe GV, Blee KA: Comparison of rhizosphere bacterial communities in Arabidopsis thaliana mutants for systemic acquired resistance. Microb Ecol 2008, 55:333-343.

82. Doornbos RF, Geraats BPJ, Kuramae EE, Van Loon LC, Bakker P: Effects of jasmonic acid, ethylene, and salicylic acid signaling on the rhizosphere bacterial community of Arabidopsis thaliana. Mol Plant Microbe Interact 2011, 24:395-407.

83. Kniskern JM, Traw MB, Bergelson J: Salicylic acid and jasmonic acid signaling defense pathways reduce natural bacterial diversity on Arabidopsis thaliana. Mol Plant Microbe Interact 2007, 20:1512-1522.

84. Ghosh S, Ghosh P, Maiti TK: Production and metabolism of indole acetic acid (IAA) by root nodule bacteria (Rhizobium): a review. J Pure Appl Microbiol 2011, 5:523-540

85. Gutierrez-Manero FJ, Ramos-Solano B, Probanza A, Mehouachi J, Tadeo FR, Talon M: The plant-growth-promoting rhizobacteria Bacillus pumilus and Bacillus licheniformis produce high amounts of physiologically active gibberellins. Physiol Plant 2001, 111:206-211.

86. Melotto M, Underwood W, Koczan J, Nomura K, He SY: Plant stomata function in innate immunity against bacterial invasion. Cell 2006, 126:969-980.

87. Glick BR: Modulation of plant ethylene levels by the bacterial enzyme ACC deaminase. FEMS Microbiol Lett 2005, 251:1-7.

88. Hassan S, Mathesius U: The role of flavonoids in root-rhizosphere signalling: opportunities and challenges for improving plant-microbe interactions. J Exp Bot 2012, 63:3429-3444.

89. Akiyama K, Hayashi $\mathrm{H}$ : Strigolactones: chemical signals for fungal symbionts and parasitic weeds in plant roots. Ann Bot 2006, 97:925-931.

90. Stracke S, Kistner C, Yoshida S, Mulder L, Sato S, Kaneko T, Tabata S, Sandal N, Stougaard J, Szczyglowski K, Parniske M: A plant receptor-like kinase required for both bacterial and fungal symbiosis. Nature 2002, 417:959-962.

91. Wang ET, Schornack S, Marsh JF, Gobbato E, Schwessinger B, Eastmond P, Schultze M, Kamoun S, Oldroyd GED: A common signaling process that promotes mycorrhizal and oomycete colonization of plants. Curr Biol 2012, 22:2242-2246.

92. Damiani I, Baldacci-Cresp F, Hopkins J, Andrio E, Balzergue S, Lecomte $P_{\text {, }}$ Puppo A, Abad P, Favery B, Herouart D: Plant genes involved in harbouring symbiotic rhizobia or pathogenic nematodes. New Phytol 2012, 194:511-522.

93. Darvill AG, Albersheim P: Phytoalexins and their elicitors - a defense against microbial infection in plants. Annu Rev Plant Physiol Plant Molec Bio/ 1984, 35:243-275.

94. Bednarek P, Osbourn A: Plant-microbe interactions: chemical diversity in plant defense. Science 2009, 324:746-748.

95. Bressan M, Roncato M-A, Bellvert F, Comte G, Haichar FEZ, Achouak W, Berge $\mathrm{O}$ : Exogenous glucosinolate produced by Arabidopsis thaliana has an impact on microbes in the rhizosphere and plant roots. ISME J 2009, 3:1243-1257.

96. Maizel JV, Mitchell HK, Burkhardt HJ: Avenacin antimicrobial substance isolated from avena sativa. 1. Isolation + antimicrobial activity. Biochemistry 1964, 3:424-426.

97. Carter JP, Spink J, Cannon PF, Daniels MJ, Osbourn AE: Isolation, characterization, and avenacin sensitivity of a diverse collection of cerealroot-colonizing fungi. Appl Environ Microbiol 1999, 65:3364-3372.

98. Osbourn AE, Clarke BR, Lunness P, Scott PR, Daniels MJ: An oat species lacking avenacin is susceptible to infection by Gaeumannomyces-graminis var tritici. Physiol Mol Plant Pathol 1994, 45:457-467.

99. Papadopoulou K, Melton RE, Leggett M, Daniels MJ, Osbourn AE: Compromised disease resistance in saponin-deficient plants. Proc Natl Acad Sci U S A 1999, 96:12923-12928.

100. Dohrmann AB, Kuting M, Junemann S, Jaenicke S, Schluter A, Tebbe CC Importance of rare taxa for bacterial diversity in the rhizosphere of Bt- and conventional maize varieties. ISME J 2013, 7:37-49.

101. Cotta SR, Dias ACF, Marriel IE, Gomes EA, van Elsas JD, Seldin L: Temporal dynamics of microbial communities in the rhizosphere of two genetically modified (GM) maize hybrids in tropical agrosystems. Antonie Van 
Leeuwenhoek 2013, 103:589-601.

102. Meyer JB, Song-Wilson Y, Foetzki A, Luginbuhl C, Winzeler M, Kneubühler Y, Matasci C, Mascher-Frutschi F, Kalinina O, Boller T, Keel C, Maurhofer M: Does wheat genetically modified for disease resistance affect root-colonizing pseudomonads and arbuscular mycorrhizal fungi? PLOS One 2013, 8:12.

103. Bittel P, Robatzek S: Microbe-associated molecular patterns (MAMPs) probe plant immunity. Curr Opin Plant Biol 2007, 10:335-341.

104. Dou DL, Zhou JM: Phytopathogen effectors subverting host immunity: different foes, similar battleground. Cell Host Microbe 2012, 12:484-495.
105. Spoel SH, Dong XN: How do plants achieve immunity? Defence without specialized immune cells. Nat Rev Immuno/ 2012, 12:89-100.

106. Bari R, Jones J: Role of plant hormones in plant defence responses. Plant Mol Biol 2009, 69:473-488.

doi:10.1186/gb-2013-14-6-209

Cite this article as: Turner TR, et al: The plant microbiome. Genome Biology 2013, 14:209. 